\title{
TG/DTG-DSC and high temperature in-situ XRD analysis of natural thaumasite
}

\author{
B. Kostova ${ }^{\mathrm{a}}$, V. Petkova ${ }^{\mathrm{b}}{ }^{*}$, Vl. Kostov-Kytin ${ }^{\mathrm{b}}$, Y. Tzvetanova $^{\mathrm{b}}$, G. Avdeev $^{\mathrm{c}}$ \\ ${ }^{a}$ New Bulgarian University, Department of Natural Sciences, 21 Montevideo Str., 1618 Sofia, Bulgaria \\ ${ }^{\mathrm{b}}$ Institute of Mineralogy and Crystallography "Acad. I. Kostov", Bulgarian Academy of Sciences, Acad. G. Bonchev Str., bldg.107, 1113, Sofia, Bulgaria \\ ' Institute of Physical Chemistry "Acad. Rostislaw Kaischew", Bulgarian Academy of Sciences, Acad. G. Bonchev Str., bldg. 11, 1113, Sofia, Bulgaria
}

\section{A R T I C L E I N F O}

\section{Keywords:}

Thaumasite

Cement-based materials

Thermal decomposition

Reaction mechanism

\begin{abstract}
A B S T R A C T
This paper investigated thermal properties of natural thaumasite, such as phase composition and reaction mechanism of thermal decomposition using simultaneous TG/DTG-DSC in Ar and Air medium up to $1673 \mathrm{~K}$, coupled with masspectrometer for analysis of evolving gases, and in-situ powder X-ray diffraction measurements. The transitional solid phases, grown with increasing of temperature at thaumasite thermal decomposition, are calcium hydrogen carbonate $\left(\mathrm{Ca}\left(\mathrm{HCO}_{3}\right)_{2}\right)$ and hydrogen sulphate $\left(\mathrm{Ca}\left(\mathrm{HSO}_{4}\right)_{2}\right)$, calcite, anhydrite, calcium silicates (wolastonite and larnite), calcium silico-carbonate (spurrite), and calcium silico-sulphate (ternesite). The thermal decomposition in both gaseous media includes the stages of dehydration, dehydroxylation, dacarbonation and desulphuration with obtaining a solid residue of varying degrees of crystallinity. The main solid phase, grown at the highest temperatures, is larnite.

Based on the obtained results it was proposed the scheme of chemical reactions, which presents the reaction mechanism of thaumasite thermal decomposition. The defined scheme has both fundamental importance by adding new details of reference data, and practical application for thaumasite identification in chemical archaeology, and in the chemistry of cement and cement-based materials.
\end{abstract}

\section{Introduction}

It is well known that the damage of ancient and modern cements and concrete are due to sulphate attack (SA) in which Ca-hydroxides and CaAl-hydrates react with sulphates and form gypsum and ettringite and most of thaumasite sulphate attack (TSA) where the bonding calciumsilicate-hydrate $(\mathrm{C}-\mathrm{S}-\mathrm{H})$ gel is destroyed by forming thaumasite [1]. Other ways of thaumasite formation are through interaction between bonding additives and/or cement substitutes, namely sulphates and carbonates and $\mathrm{C}-\mathrm{S}-\mathrm{H}$ gel [2]. The thaumasite has no binding properties and increasing its amount leads to aging and destruction of cements [3-11]. These processes are observed at cement plasters in old buildings of archaeological significance as a result of prolonged exposure to the external environment - weathering [7,8,12-17].

To study TSA, it is appropriate to examine the thermal properties of thaumasite, such as phase composition and reaction mechanism of thermal decomposition. The thaumasite from cement composite is not suitable for this purpose, due to its fine grained structure and coinciding temperature range $\left(500-800^{\circ}\right)$ of $\mathrm{C}-\mathrm{S}-\mathrm{H}$ phases dihydroxylation and carbonate phases decomposition [12,18]. Due to the described limitations, natural thaumasite is much more suitable for such studies.

Much of the thaumasite research is structural, aiming distinguishing it from ettringite. When both mineral are in cement composite, it is difficult to identify, as they belong to the same mineral group. The thermal examination of natural $[19,20]$ and cement-forming thaumasite are studied by many researchers [18,21-29], as this is achieved by comparison with ettringite. In literature, the mechanism of its thermal decomposition is shown by general description of dehydration process, presenting the solid anhydrous residuum by $\mathrm{CaSiO}_{3} \cdot \mathrm{CaCO}_{3} \cdot \mathrm{CaSO}_{4}$ with valuable data from thermodynamic measurements [23-26]. The detailed clarification of thaumasite thermal decomposition mechanism will be most successful by using evolving gases analysis and phase analysis of end products at each stage of thermal decomposition. This approach will provide evidence of the decomposition process and it can be expressed by chemical equations. To our best knowledge such investigations have not been made for thaumasite.

In this work has been investigated natural thaumasite from the Iglika deposit, SE Bulgaria to define its thermal properties, phase composition

\footnotetext{
* Corresponding author.

E-mail address: vpetkova@clmc.bas.bg (V. Petkova).
} 
and reaction mechanism of thermal decomposition. The published thermal decomposition of selected raw thaumasite from the Iglika deposit, SE Bulgaria has been investigated in air medium only [19].

The following methods has been used for the purpose of the study: powder X-ray diffraction (PXRD), Fourier-Transform Infrared (FTIR) spectroscopy as well as combination of simultaneous TG/DTG-DSC, coupled with masspectrometer for analysis of evolving gases, and insitu PXRD) measurements. The thermal investigations are made in two gas mediums ( $\mathrm{Ar}$ and air) to define their impact on the thaumasite decomposition and formation of new solid phases. The investigation at air gas medium was chosen because $\mathrm{Ca}, \mathrm{Si}, \mathrm{C}$ and $\mathrm{S}$ are in their highest valence in thaumasite and no oxidation-reduction processes are expected to occur during its thermal decomposition [30]. On the other hand, since some of the decomposition reactions occur with oxygen emission (decarbonization and desulphuration), it is assumed that part of the thermal reactions will be incomplete (for example, desulphuration). Therefore, the inert Ar gas medium was chosen in order to monitor the path of these reactions. In inert environment, all reactions will take place with a higher conversion degree and at lower temperature. The mass-spectrometric measurements provide additional data of the gas emissions during solid phases decomposition. The in-situ PXRD analysis were made at temperatures following the thermal effects at simultaneous TG/DTG-DSC.

The obtained results are fundamental and can be used as a reference for a detailed study of: (i) ancient cements by determining the source materials and technology of their production, their current state and possibilities for their conservation or restoration and (ii) modern cement in the order to predict the thaumasite sulphate attack.

\section{Raw material and methods}

\subsection{Raw material}

This paper investigated thaumasite from the Iglika skarn deposit, Srednogorie structural metallogenic zone, SE Bulgaria. The formation of Iglika deposit is associated with the intrusion of the Upper Cretaceous diorite body in the host andesite, pyroclastic rocks and Triassic marbles, dolomites and schists. The magnesian (monticellite) and calcic skarns are developed at the contact with carbonate rocks [31]. The monticellite skarns are cut by mono-mineral thaumasite veins (rare in association with xonotlite) with a thickness up to $5-6 \mathrm{~cm}$. The thaumasite is of parallel-acicular aggregates, yellow in color and white after weathering. The chemical composition of thaumasite (wt $\%)$ is: $\mathrm{SiO}_{2}-9.67 \%, \mathrm{CaO}-$ $27.71 \%, \mathrm{MgO}-0.10 \%, \mathrm{SO}_{3}-13.36 \%, \mathrm{CO}_{2}-7.57 \%, \mathrm{H}_{2} \mathrm{O} 41.61 \%$ [32]. The investigated raw sample is bi-mineral - thaumasite and calcite.

\subsection{Methods}

The crystal structure data of thaumasite, reported by Jacobsen et al. (2003) [33,34], has been used to perform the phase identification in this study and to construct Fig. 1 [35].

The Fourier-Transform Infrared (FTIR) spectra were registered on Bruker Tensor 37 spectrometer, covering the range $400-4000 \mathrm{~cm}^{-1}$, using $\mathrm{KBr}$ pellet technique. A resolution of $2 \mathrm{~cm}^{-1}$ was used collecting 60 scans for each sample.

The time-resolved high-temperature powder X-ray diffraction (HTPXRD) measurements were collected at PANalytical Empyrean equipped with a multichannel detector (Pixel 3D) using ( $\mathrm{Cu} \mathrm{K \alpha} 45 \mathrm{kV}-40 \mathrm{~mA}$ ) radiation in the $10-80^{\circ} 2 \theta$ range, with a scan step of $0.026^{\circ}$ for $33 \mathrm{~s}$. The in-situ HT-PXRD measurements were carried out by means of an Anton Paar HT-16 camera with a sample directly heated with a heating filament from RT to $1073 \mathrm{~K}$. All experiments were conducted on air with a heating rate of about $10 \mathrm{~K}$ per minute. Phase identification at each particular temperature step has been performed using various searchmatch programs software as well as data from the Inorganic Crystal Structure Database (ICSD) [36,33].

Thermal analyses were performed using simultaneous TG/DTG-DSC, SETSYS2400 thermal analyzer (SETARAM, France), coupled with OmniStar mass-spectrometer in the temperature range: room temperature (RT) $-1673 \mathrm{~K}$, in two gas mediums - air and argon, with a heating rate of $10 \mathrm{~K} \cdot \mathrm{min}^{-1}$. The operational characteristics of the TG/DTG-DSC system were: sample mass of $18.0 \pm 2.0 \mathrm{mg}$ (mass resolution of $0.02 \mu \mathrm{g}$ ); ceramic crucible with a volume of $100 \mu \mathrm{L}$.

\section{Results}

\subsection{Crystal structure draw}

The thaumasite has the theoretical formula $\mathrm{Ca}_{3} \mathrm{Si}(\mathrm{OH})_{6}\left(\mathrm{SO}_{4}\right)$ $\left(\mathrm{CO}_{3}\right) \cdot 12 \mathrm{H}_{2} \mathrm{O}$ and belongs to the ettringite mineral group. Thaumasite is the only mineral known to contain silicon in six-coordination with hydroxyl groups. First single-crystal X-ray diffraction evidence for this has been obtained by Edge and Taylor [37,38]. These authors found that thaumasite crystallizes in the hexagonal, P6 ${ }_{3}$, S.G. $(a=11.04, c=10.39$ $\AA, \mathrm{Z}=2$ ) and that its structure is "based on columns of empirical composition $\left[\mathrm{Ca}_{3} \mathrm{Si}(\mathrm{OH})_{6} \cdot 12 \mathrm{H}_{2} \mathrm{O}\right]^{4+}$ running parallel to $c$, between which occur the $\left[\mathrm{CO}_{3}\right]^{2-}$, $\left[\mathrm{SO}_{4}\right]^{2-}$ groups and $\mathrm{H}_{2} \mathrm{O}$ molecules."

Crystal structure determinations of the same material made later only elucidate some details, however, confirm in general its arrangement. Thus, the crystal structure data of thaumasite reported by Jacobsen et al. (2003) [38] has been used as a model (data_98394-ICSD) to draw Fig. 1 and to perform the phase identification in the following sections.

\subsection{PXRD analysis}

Fig. 2 shows the result of the PXRD analysis, phase composition of the studied sample - mainly thaumasite (data_98394-ICSD) with some quantity of calcite.
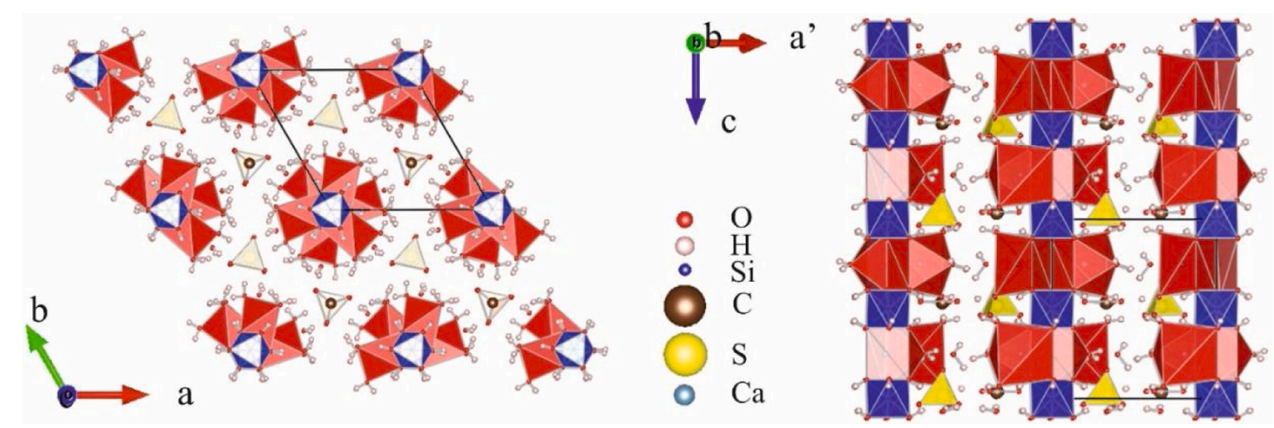

Fig. 1. General view of the crystal structure of thaumasite. 


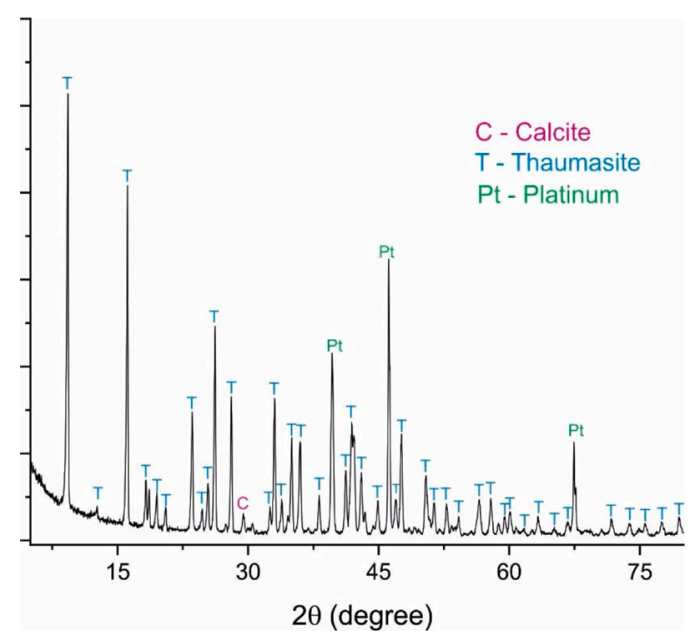

Fig. 2. PXRD pattern of raw sample (measured at RT).

\subsection{FTIR spectroscopy}

The results from FTIR spectroscopy are present in Fig. 3 and Table 1. The FTIR absorption bands are assigned as $\left[\mathrm{CO}_{3}\right]^{2-},\left[\mathrm{SO}_{4}\right]^{2-},[\mathrm{Si}$ $\left.(\mathrm{OH})_{6}\right]^{2-}$ and $[\mathrm{OH}]^{-}$anions as well as $\mathrm{H}_{2} \mathrm{O}$ molecules.

The bands at 2458 and $1394 \mathrm{~cm}^{-1}$ are asymmetric stretching vibration, where at $887 \mathrm{~cm}^{-1}$ is symmetric bending vibration of $\left[\mathrm{CO}_{3}\right]^{2-}[39$, 40].

The bands at 1099 and $1066 \mathrm{~cm}^{-1}$ are assigned as asymmetric stretching vibration of $\left[\mathrm{SO}_{4}\right]^{2-}$. Those at 590 and $638 \mathrm{~cm}^{-1}-$ as asymmetric bending vibration $\left[\mathrm{SO}_{4}\right]^{2-}[40]$.

Most characteristic bands for thaumasite are at $497 \mathrm{~cm}^{-1}$ (Si-O bending vibration) and $749 \mathrm{~cm}^{-1}$ (Si-O stretching vibration) in [Si $\left.(\mathrm{OH})_{6}\right]^{2-}$ - reflected to the octahedral coordination of the silicon cation [28,39-42].

The peaks at 3469, 3428, 3399, 3050, 3239 and $2861 \mathrm{~cm}^{-1}$ are assigned as $\mathrm{O}-\mathrm{H}$ symmetric stretching vibration [41], where 1695 and $1648 \mathrm{~cm}^{-1}$ as $\mathrm{O}-\mathrm{H}$ symmetric bending vibration of crystal bonded water.

The bands at $3502 \mathrm{~cm}^{-1}$ and $1648 \mathrm{~cm}^{-1}$ are assigned as symmetric stretching vibration and symmetric bending vibration, respectively of structurally bonded $\mathrm{O}-\mathrm{H}$. At $647 \mathrm{~cm}^{-1}$ is situated libration mode of structural bonded $\mathrm{OH}^{-}[40,41,43,44]$.

The bands 2327 and $2250 \mathrm{~cm}^{-1}$ are assigned to $\mathrm{CO}_{2}$ from the air [45].

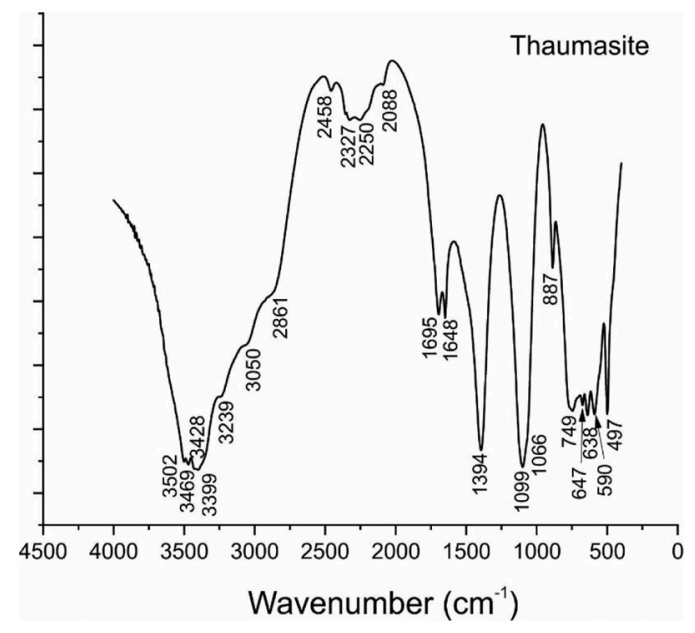

Fig. 3. FTIR spectrum of thaumasite (measured at RT).

\subsection{Thermal analysis}

The results from thermal investigations of raw material are presented in Fig. 4a, b and Table 2.

The thermal decomposition takes place in five stages, well defined from five temperature ranges at both gas mediums. Such differentiation is an advantage, as it is easier to calculate the associated mass losses (ML). The most intense ML have been measured during the 1st stage (temperature range $345.6 \mathrm{~K}-493.8 \mathrm{~K}$ in $\mathrm{Ar}$ and $341.3 \mathrm{~K}-530.8 \mathrm{~K}$ in air) - 38-39\%, related to the intense release of water vapors. In the 2nd stage $(580-830 \mathrm{~K})$ the $\mathrm{CO}_{2}, \mathrm{SO}_{2}, \mathrm{O}^{2}$,- and water vapors release have been measured with ML of $4.09 \%$ in Ar and $4.67 \%$ in air. During the $3 r d$ stage $(900-1030 \mathrm{~K})$ - the release of $\mathrm{CO}_{2}$ and $\mathrm{O}^{2-}$ with $\mathrm{ML}$ of $1.51 \%$ in $\mathrm{Ar}$ and $1.11 \%$ in air. In the 4th stage $(1180-1320 \mathrm{~K})$ - the release of $\mathrm{SO}_{2}$ and $\mathrm{O}^{2-}$ with the ML of $1.88 \%$ in $\mathrm{Ar}$ and $1.14 \%$ in air. The 5th stage is the high temperature $(1400-1670 \mathrm{~K})$ with approximately $10 \% \mathrm{ML}$ with the $\mathrm{SO}_{2}$ and $\mathrm{O}^{2-}$ evolving.

A comparison of the two gaseous media analyses shows: (i) the temperature intervals of the five temperature ranges are close. In Ar gas medium they are approximately $50 \mathrm{~K}$ lower; (ii) the ML in Ar gas medium are $0.50-2.85 \%$ higher for the individual stages; (iii) at air medium, the 5th decomposition stage does not complete at the final heating temperature, while in Ar medium - thermal decomposition ends during the 5th stage (the TG the curve passes in a straight line) with approximately $3 \%$ higher ML (Table 2).

\subsection{In-situ PXRD analysis}

The in-situ PXRD patterns obtained after sample heating are shown in Fig. 5. The heating is done at temperatures $393,673,773,873,973$, and $1073 \mathrm{~K}$, following those of the thermal effects registered by simultaneous TG/DTG-DSC analysis. The identified phases are present in Table 3.

The platinum strongest reflections at 39.75 (111), 46.23 (200), 67.45 (220), 81.24 (311), and 85.68 (222) 20, $\left(^{\circ}\right)$ (data_649490-ICSD) are present in each PXRD pattern due to the impact of the Pt substrate used in the experiments (Fig. 5). Besides this, the phase identification gets even more complicated during the in-situ time-resolved high-temperature investigations due to the thermal extensions affecting differently the phases involved in the studied process. Typically, this is expressed in their reflections D-space shifts towards the high $2 \theta$ range and is also accompanied by certain changes of their intensity. Nevertheless, in this section, an attempt is made to explain the thermal evolution and the phase transformations of the raw material based on the data of the presented here PXRD patterns obtained at the selected above mentioned temperatures.

- The thaumasite crystal structure (data_98394-ICSD) remains intact up to $373 \mathrm{~K}$.

- At $398 \mathrm{~K}$ only the strongest line of the raw thaumasite can be registered at $13.42(100) 2 \theta,\left({ }^{\circ}\right)$. This means that a substantial part of the mineral has undergone thermal decomposition and has turned into X-ray amorphous substance as evidenced by the halo appearing within the $24-35^{\circ} 2 \theta$ range. The reflection at $29.50^{\circ} 2 \theta$ could be recognized as being the strongest line of the mineral raw calcite (data_40113-ICSD). It corresponds to the (104) reflection with $\mathrm{d}=$ $3.039 \AA$ and it can readily be detected at the room temperature PXRD pattern.

- Between $673 \mathrm{~K}$ and $773 \mathrm{~K}$ the PXRD patterns of the studied material look much the same as that one collected at $293 \mathrm{~K}$ the only difference being the complete absence of the raw thaumasite and the decrease of the amorphous halo upon heating indicating certain activation of this substance preceding the phase growth registered at the next stages.

- At $873 \mathrm{~K}$ the appearance of anhydrite (data_1956-ICSD) is registered and calcite. The anhydrite phase does not undergo any changes upon 
Table 1

FTIR spectrum bands of Thaumasite.

\begin{tabular}{|c|c|c|c|c|c|}
\hline \multirow[b]{2}{*}{ No } & \multicolumn{5}{|l|}{ Frequency, $\left(\mathrm{cm}^{-1}\right)$} \\
\hline & $\begin{array}{l}\nu_{\mathrm{s}} \text { (symmetric stretching } \\
\text { vibration) }\end{array}$ & $\begin{array}{l}\delta_{\mathrm{s}} \text { (symmetric bending } \\
\text { vibration) }\end{array}$ & $\begin{array}{l}\nu_{\text {as }} \text { (asymmetric stretching } \\
\text { vibration) }\end{array}$ & $\begin{array}{l}\delta_{\text {as }} \text { (asymmetric bending } \\
\text { vibration) }\end{array}$ & $\begin{array}{l}\text { Associated bonds in Thaumasite } \mathrm{Ca}_{3}\left[\mathrm{Si}(\mathrm{OH})_{6}\right] \\
\left(\mathrm{SO}_{4} \cdot \mathrm{CO}_{3}\right) \times 12 \mathrm{H}_{2} \mathrm{O}\end{array}$ \\
\hline 1. & 3502 & 1648 & - & - & structural bonded $[\mathrm{OH}]^{-}$ \\
\hline 2. & $3469-3399,2861-3239$ & $1695-1648$ & - & - & $\mathrm{O}-\mathrm{H}$ in crystal bonded water \\
\hline 3. & 647 & - & - & - & Libration mode of structural bonded $[\mathrm{OH}]^{-}$ \\
\hline 4. & - & 887 & 2458,1394 & - & $\mathrm{C}-\mathrm{O}$ in $\left[\mathrm{CO}_{3}\right]^{2-}$ \\
\hline 5. & - & - & 1066,1099 & 590,638 & $\mathrm{~S}-\mathrm{O}$ in $\left[\mathrm{SO}_{4}\right]^{2-}$ \\
\hline 6. & 749 & 497 & - & - & $\mathrm{Si}-\mathrm{O}$ in $\left[\mathrm{Si}(\mathrm{OH})_{6}\right]^{2-}$ \\
\hline
\end{tabular}

a

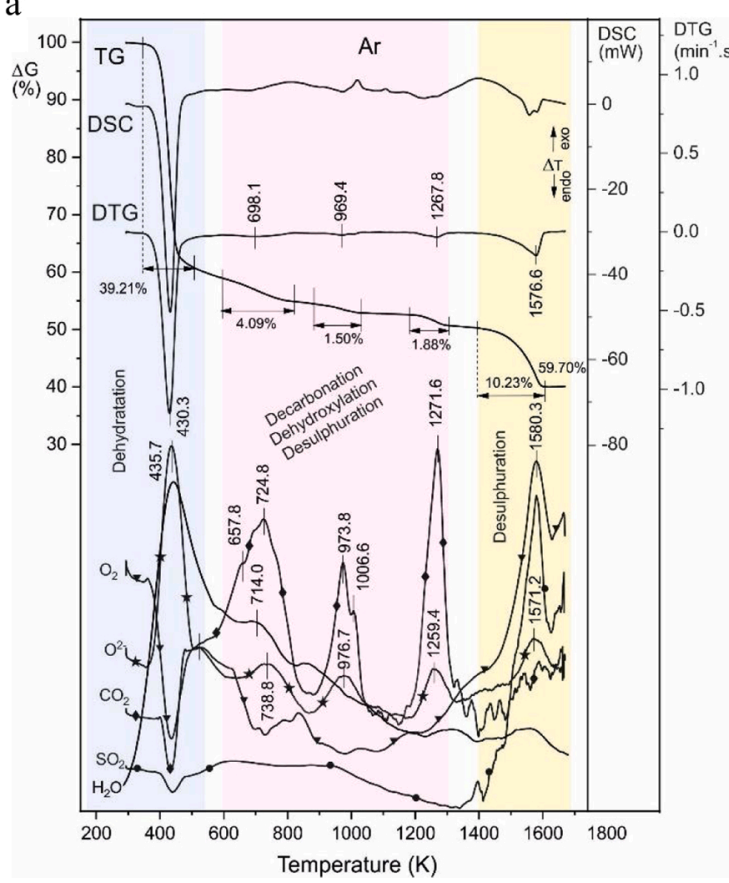

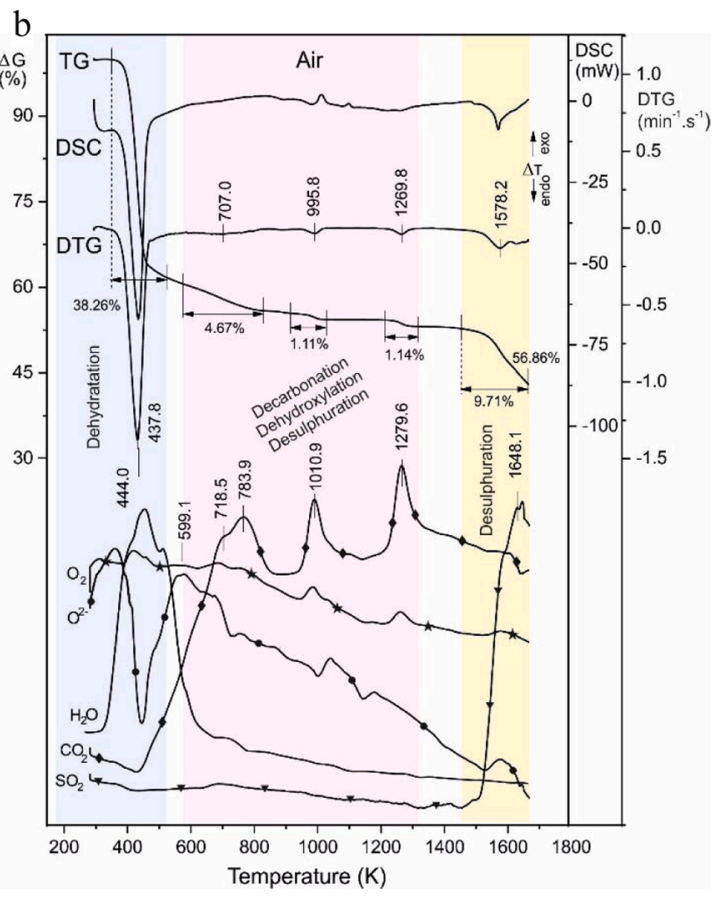

Fig. 4. a TG/DTG-DSC in Ar gas medium (heating up to $1673 \mathrm{~K}$ ). b TG/DTG-DSC in air gas medium (heating up to $1673 \mathrm{~K}$ ).

Table 2

Temperature ranges and ML in Ar and air medium with Evolved gas phases.

\begin{tabular}{|c|c|c|c|c|c|c|c|}
\hline \multirow[b]{2}{*}{ Thermal decomposition stages } & \multicolumn{3}{|c|}{ Ar gas medium } & \multicolumn{3}{|c|}{ Air gas medium } & \multirow[b]{2}{*}{ Evolved gas phases } \\
\hline & $\begin{array}{l}\mathrm{T}_{\text {infl }}{ }^{*} \\
\mathrm{~K}\end{array}$ & $\begin{array}{l}\text { Temp. range } \\
\mathrm{K}\end{array}$ & $\begin{array}{l}\mathrm{ML}^{* *} \\
\%\end{array}$ & $\begin{array}{l}\mathrm{T}_{\text {infl }} \\
\mathrm{K}\end{array}$ & $\begin{array}{l}\text { Temp. range } \\
\mathrm{K}\end{array}$ & $\begin{array}{l}\mathrm{ML}^{* *} \\
\%\end{array}$ & \\
\hline $1^{\text {st }}$ & 430.3 & $345.6-493.8$ & 39.21 & 437.8 & $341.3-530.8$ & 38.26 & $\mathrm{H}_{2} \mathrm{O}, \mathrm{O}^{2-}$ \\
\hline $2^{\text {nd }}$ & 698.1 & $626.5-820.8$ & 4.09 & 707.0 & $580.1-833.4$ & 4.67 & $\mathrm{H}_{2} \mathrm{O}, \mathrm{CO}_{2}, \mathrm{SO}_{2}, \mathrm{O}^{2-}$ \\
\hline $3^{\text {rd }}$ & 969.4 & $908.2-1030.8$ & 1.51 & 995.8 & $918.8-1033.0$ & 1.11 & $\mathrm{CO}_{2}, \mathrm{O}^{2-}$ \\
\hline $4^{\text {th }}$ & 1267.8 & $1180.0-1304.5$ & 1.88 & 1269.8 & $1216.8-1322.9$ & 1.14 & $\mathrm{CO}_{2}, \mathrm{O}^{2-}$ \\
\hline $5^{\text {th }}$ & 1576.6 & $1394.1-1606.8$ & 10.23 & 1578.2 & $1457.6-1669.1$ & 9.71 & $\mathrm{SO}_{2}, \mathrm{O}^{2-}$ \\
\hline all five stages & & & 56.92 & & & 54.89 & Summarized ML \\
\hline Interval RT $-1673 \mathrm{~K}$ & 59.71 & & & 56.86 & & & Total measured ML \\
\hline
\end{tabular}

$\mathrm{T}_{\text {infl. }}{ }^{*}$ - Temperature in inflection point; $\mathrm{ML}^{* *}-$ Mass losses.

the further thermal treatment. Simultaneously "a bunch" of calcium silicate phases starts to grow. At this stage, it has not been possible to reliably identify and distinguish them so this has been made during the subsequent stages.

- Between $973 \mathrm{~K}$ and $1073 \mathrm{~K}$ competitively occurring phase formations have been registered on the account of the gradually diminishing amorphous halo that supplies their growth with structural units. The following phases have been more or less reliably identified in the PXRD pattern collected at $1073 \mathrm{~K}$ : ternesite $\mathrm{Ca}_{5}\left(\mathrm{SiO}_{4}\right)_{2} \mathrm{SO}_{4}$ (data_85123-ICSD); the monoclinic larnite $\mathrm{Ca}_{2} \mathrm{SiO}_{4}$ (data_79553ICSD); the orthorhombic polymorph $\gamma$-dicalcium silicate $\mathrm{Ca}_{2} \mathrm{SiO}_{4}$
(data_18179-ICSD); and the logically appearing at higher temperatures hexagonal polymorph $\alpha$-dicalcium silicate $\mathrm{Ca}_{2} \mathrm{SiO}_{4}$ (data_182054-ICSD). Peak overlapping is strongly expressed for the calcium disilicate polymorph phases and additionally hampers their precise identification.

Phase identifications of the solid residues left after the thermal decomposition of the bi-phase sample with predominant thaumasite content in the two gaseous media have been performed in order to determine the run-products at $1673 \mathrm{~K}$ (Fig. 6). The results are presented in Table 3 (rows 7,8 ) and Fig. 6 . The results give evidence for the 


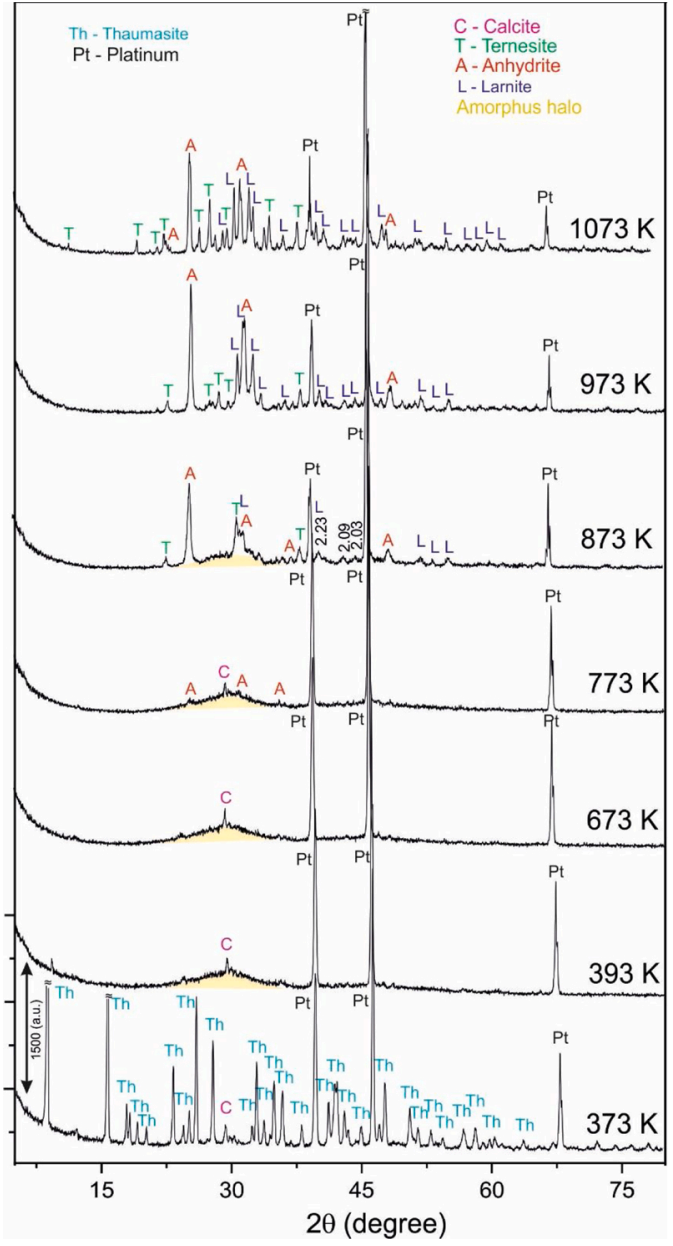

Fig. 5. In-situ PXRD patterns of thaumasite. formation of various modifications of dicalcium silicate $\mathrm{Ca}_{2} \mathrm{SiO}_{4}$ (monoclinic and orthorhombic), $\mathrm{CaSiO}_{3}$ and calcium oxide, all of them of better crystallinity when heated in air gaseous medium. The reflexes of wollastonite and calcium oxide overlap with those of larnite, so their presence in the solid residue of the heating is considered very probably.

\section{Discussions}

The raw thaumasite begins to decompose immediately, in the 1st stage of thermal decomposition, as the raw calcite stays stable in this stage. According to in-situ PXRD analysis, the substantial part of thaumasite has been decomposed and turned into X-Ray amorphous phase

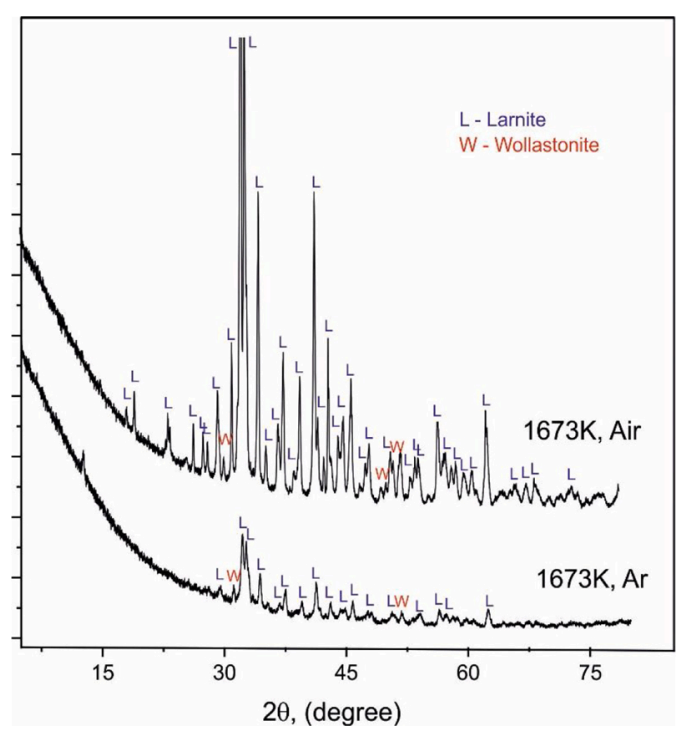

Fig. 6. PXRD patterns of thaumasite after heating up to $1673 \mathrm{~K}$ in $\mathrm{Ar}$ and Air gas media.

Table 3

Results from the in-situ PXRD phase analyses.

\begin{tabular}{|c|c|c|}
\hline No & Temperature (K) & Identified phases \\
\hline & & Thaumasite, $\mathrm{Ca}_{3} \mathrm{Si}(\mathrm{OH})_{6}\left(\mathrm{CO}_{3}\right)\left(\mathrm{SO}_{4}\right) \cdot 12 \mathrm{H}_{2} \mathrm{O}$, (data_98394-ICSD) \\
\hline \multirow[t]{3}{*}{1.} & 373 & Calcite, $\mathrm{CaCO}_{3}$, (data_40113-ICSD) \\
\hline & & Platinum, Pt, (data_649490-ICSD) \\
\hline & & Calcite, $\mathrm{CaCO}_{3},(47-1743)$, (data_40113-ICSD) \\
\hline \multirow[t]{3}{*}{2.} & 393 & Platinum, Pt, (data_649490-ICSD) \\
\hline & & Amorphous halo \\
\hline & & Calcite, $\mathrm{CaCO}_{3}$, (47-1743), (data_40113-ICSD) \\
\hline \multirow[t]{3}{*}{3.} & 673 & Platinum, Pt, (data_649490-ICSD) \\
\hline & & Amorphous halo \\
\hline & & Calcite, $\mathrm{CaCO}_{3}$, (47-1743), (data_40113-ICSD) \\
\hline \multirow[t]{3}{*}{4.} & 773 & Platinum, Pt, (data_649490-ICSD) \\
\hline & & Amorphous halo \\
\hline & & Calcite, $\mathrm{CaCO}_{3}$, (data_40113-ICSD) \\
\hline \multirow{5}{*}{5.} & 873 & Platinum, Pt, (data_649490-ICSD) \\
\hline & $8 / 3$ & Anhydrite, $\mathrm{CaSO}_{4}$, (data_1956-ICSD) \\
\hline & & Amorphous halo \\
\hline & & Platinum, Pt, (data_649490-ICSD) \\
\hline & & Anhydrite, $\mathrm{CaSO}_{4}$, (data_1956-ICSD) \\
\hline \multirow{5}{*}{6.} & & Larnite-monoclinic, $\mathrm{Ca}_{2} \mathrm{SiO}_{4}$, (data_79553-ICSD) \\
\hline & 973- 1073 & Larnite-orthorhombic, $\mathrm{Ca}_{2} \mathrm{SiO}_{4}$, (data_18179-ICSD) \\
\hline & & Larnite-hexagonal, $\mathrm{Ca}_{2} \mathrm{SiO}_{4}$, (data_182054-ICSD) \\
\hline & & Ternesite, $\mathrm{Ca}_{5}\left(\mathrm{SiO}_{4}\right)_{2}\left(\mathrm{SO}_{4}\right)$, (data_85123-ICSD) \\
\hline & & Larnite-monoclinic, $\mathrm{Ca}_{2} \mathrm{SiO}_{4}$, (data_79553-ICSD) \\
\hline \multirow[t]{3}{*}{ 7.* } & 1673 Heating in Ar & Larnite-orthorhombic, $\mathrm{Ca}_{2} \mathrm{SiO}_{4}$, (data_18179-ICSD) \\
\hline & & Wollastonite, $\mathrm{CaSiO}_{3}$, (data_26553 -ICSD) \\
\hline & & Larnite-monoclinic, $\mathrm{Ca}_{2} \mathrm{SiO}_{4}$, (data_79553-ICSD) \\
\hline \multirow[t]{2}{*}{ 8.* } & 1673 Heating in Air & Larnite-orthorhombic, $\mathrm{Ca}_{2} \mathrm{SiO}_{4}$, (data_18179-ICSD) \\
\hline & & Wollastonite, $\mathrm{CaSiO}_{3}$, (data_26553 -ICSD) \\
\hline
\end{tabular}

" Phase identification performed on ex-situ collected PXRD data. 
(Table 3) during the 1st stage. The registered evolved gas phases are only $\mathrm{H}_{2} \mathrm{O}$ and $\mathrm{O}^{2-}$ (Table 2). These results, and their comparison with literature, enable to assert that dehydration has been the main thermal reaction in which almost all crystal water has been released (Eq. 7) [23, 24]. For identification of the registered amorphous phase, and for clarification the phases, involved in reaction mechanism during this stage, the thermal analysis are of essential importance. The theoretical ML from dehydration of thaumasite are a total of $51.12 \%$ (OH-groups $16.40 \%$ and $34.72 \% \mathrm{H}_{2} \mathrm{O}$ molecules). The measurements show that temperature range $340-530 \mathrm{~K}$, occurs $38-39 \% \mathrm{ML}$ only (Table 2), i. e. part of the water stay bonded in solid phases. The measured ML correspond to $13.5-14.0$ mol bonded water. The registered lower ML in comparison with theoretical, suggest that part of the water is included in the newly formed solid phases as calcium hydrogen carbonate $\mathrm{Ca}$ $\left(\mathrm{HCO}_{3}\right)_{2}$, calcium hydrogen sulphate $\mathrm{Ca}\left(\mathrm{HSO}_{4}\right)_{2}$, and probably $\mathrm{Ca}(\mathrm{OH})_{2}$ (equation 7a). Their formation could be accomplished during dehydration in conditions of increasing both, temperature, and partial pressure of water vapor [23]. Drabik et. al [23]. report the shortening of bonds lengths between water molecules and carbonate, as well as sulphate ions during thaumasite thermal decomposition at temperatures up to $580 \mathrm{~K}$. It is assumed, that at this stage, the thaumasite dehydration, and for-

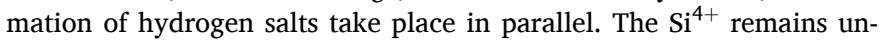
defined in the amorphous phase, probably as $\mathrm{SiO}_{2}$. The theoretical ML of crystal bonded water from thaumasite with the simultaneous formation of calcium hydrogen carbonate are $39.06 \%$. The measurements show ML of $38.26 \%$ at air medium and $39.21 \%$ at Ar medium, demonstrating good comparability with the theoretically calculated. During the 2nd stage of thermal decomposition ( $580-830 \mathrm{~K}$ ), the emission of $\mathrm{H}_{2} \mathrm{O}, \mathrm{CO}_{2}$ and $\mathrm{SO}_{2}$ has been registered. The ML in this stage are of $4.09 \%-4.67 \%$, accompanied by gradually diminishing amorphous halo after in-situ PXRD. The registered $\mathrm{H}_{2} \mathrm{O}$ emission marks the release of all crystal water, i.e. the dehydration occurs (Eq. 8). The solid anhydrous residuum is represented by $\mathrm{CaSiO}_{3} \cdot \mathrm{CaCO}_{3} \cdot \mathrm{CaSO}_{4}[23,24]$ or by mechanical mixture of mentioned above components (Eq. 8a). The $\mathrm{CO}_{2}$ and $\mathrm{SO}_{2}$ emissions are not typical for this temperature range. The obtained results could be explained by simultaneously running the dehydroxylation process of $\mathrm{Ca}\left(\mathrm{HCO}_{3}\right)_{2}, \mathrm{Ca}(\mathrm{OH})_{2}$, and $\mathrm{Ca}\left(\mathrm{HSO}_{4}\right)_{2}$; decarbonation of $\mathrm{Ca}$ $\left(\mathrm{HCO}_{3}\right)_{2}$; and desulphuration of $\mathrm{Ca}\left(\mathrm{HSO}_{4}\right)_{2}$ (Eqs. 9-11). The in-situ PXDR confirms the described processes by registered newly-formed solid phases - $\mathrm{CaSO}_{4}, \mathrm{CaCO}_{3}$, and $\mathrm{CaO} / \mathrm{CaSiO}_{3}$. In accordance with newly-formed phases and the results of mass-spectrometric analysis, 1 mol of $\mathrm{CO}_{2}$ and $\mathrm{SO}_{2}$ remains bounded in $\mathrm{CaCO}_{3}$ and $\mathrm{CaSO}_{4}$, until the other $1 \mathrm{~mol}$ of $\mathrm{CO}_{2}$ and $\mathrm{SO}_{2}$ evolved with the gas phase. Both minerals are resistant up to significantly higher temperatures and their decomposition occurs in later stages.At 2nd, 3rd and 4th stages, the main process of temperature decomposition has been associated with $\mathrm{CO}_{2}$ release - decarbonation process with a total low ML. The theoretical ML from decarbonation are $7.07 \%$, and the measured are of $7.48 \%$ in $\mathrm{Ar}$ gas medium and $6.92 \%$ in air (Table 2, Fig. 4). The registered low ML prove the redistribution of components during these stages. The 3rd stage has been characterized by the emission of $\mathrm{CO}_{2}$ and $\mathrm{O}^{2-}$ due to calcite decarbonation in the temperature range 900-1030 K with 1-1.50 $\%$ ML. This temperature range coincide well with the decomposition temperatures of natural/synthetic calcite from our previous investigations [46-48]. The calcite decarbonation is carried out in accordance with equilibrium $\mathrm{CO}_{3}^{2-} / \mathrm{CO}_{2}$ with $\mathrm{CO}_{2}$ and $\mathrm{O}^{2-}$ release (Eqs. 12-15). The results from simultaneous thermal analysis supposed solid phases formation : larnite $-\mathrm{Ca}_{2} \mathrm{SiO}_{4}[18]$, ternesite $-\mathrm{Ca}_{5}\left(\mathrm{SiO}_{4}\right)_{2}\left(\mathrm{SO}_{4}\right)$ $[19,49]$, and spurrite $-\mathrm{Ca}_{5}\left(\mathrm{SiO}_{4}\right)_{2}\left(\mathrm{CO}_{3}\right)[20,50]$. Their crystallization takes place in the thermal heating process, not related to ML. The in-situ PXRD confirms crystallization of ternesite and three high temperature polymorphic modifications of larnite (Table 3). Their formation is possible via unconsumed $\mathrm{SiO}_{2}$ and $\mathrm{CaO}$, obtained by decomposition in 1 st stage, and decarbonation in current stage. Confirmation of the spurrite formation has been obtained from gas analysis in the 4th stage of thermal decomposition, namely emission of $\mathrm{CO}_{2}$, as it is well known that calcite is decomposed at this 3rd stage.

During the 4th stage, the high temperature (1180-1320 K) decarbonation of spurrite occurs with $\mathrm{CO}_{2}$ and $\mathrm{O}^{2-}$ emission (Eqs. 16,17). This process corresponds to our earlier studies in other systems [50] and to results by the others [51-53].

During the 5th stage, gas analysis registered both $\mathrm{SO}_{2}$ and $\mathrm{SO}_{2}$ emissions. The identified from in-situ PXRD phases with $\mathrm{SO}_{2}$ are anhydrite and ternesite. The desulphuration of the latter takes place with 10 $\%$ ML which are lower than theoretical (12.86 \%) (Eqs. 18-20). This confirms partly $\mathrm{SO}_{2}$ emission at lower temperature, namely during the earlier 2nd stage, i.e. $\mathrm{Ca}\left(\mathrm{HSO}_{4}\right)$-decomposition.

The emission of $\mathrm{O}^{2-}$ can be explained by the equilibrium of the emitting gases and oxygen at temperatures above $620 \mathrm{~K}$ for $\left[\mathrm{HCO}_{3}\right]-/$ $\left[\mathrm{CO}_{3}\right]^{2-}[54-57]$ by the equations:

$$
\begin{aligned}
& {[\mathrm{OH}]^{-} /\left[\mathrm{HCO}_{3}\right]^{-} /\left[\mathrm{CO}_{3}\right]^{2-}} \\
& 2\left[\mathrm{HCO}_{3}\right]^{-} \leftrightarrow \mathrm{H}_{2} \mathrm{O}+2 \mathrm{CO}_{2} \\
& 2[\mathrm{OH}]^{-} \rightarrow \mathrm{H}_{2} \mathrm{O}+\mathrm{O}^{2-} \\
& {\left[\mathrm{CO}_{3}\right]^{2-} \leftrightarrow \mathrm{CO}_{2}+1 / 2 \mathrm{O}_{2}} \\
& \quad \text { Similarly, for }\left[\mathrm{HSO}_{4}\right]^{-} \\
& 2\left[\mathrm{HSO}_{4}\right]^{-} \leftrightarrow \mathrm{H}_{2} \mathrm{O}+2 \mathrm{SO}_{2} \\
& {\left[\mathrm{SO}_{4}\right]^{2-} \leftrightarrow \mathrm{SO}_{3}+1 / 2 \mathrm{O}_{2}} \\
& \mathrm{SO}_{3} \leftrightarrow \mathrm{SO}_{2}+1 / 2 \mathrm{O}_{2}
\end{aligned}
$$$$
\text { Similarly, for }\left[\mathrm{HSO}_{4}\right]^{-} /\left[\mathrm{SO}_{4}\right]^{2-}[57,58]
$$

The measured total ML of $59.71 \%$ (Table 2) coincide well with the theoretical - $60.77 \%$. This proves the equations described above. In accordance with the obtained results has been calculated the transformation degree of the raw material to the end-phases of decomposition: $98.24 \%$ in Ar, and $93.57 \%$ in air mediums The lower percent of transformation in air medium is via oxygen emission during Eqs. 2,4 and 5 , which shifts the equilibrium to higher temperatures.

Based on the obtained results, and literature data, a complete scheme of natural thaumasite thermal decomposition is presented:

1st stage - 340-530 K, Dehydration of thaumasite [23,24]

$$
\begin{gathered}
\mathrm{Ca}_{3} \mathrm{Si}(\mathrm{OH})_{6}\left(\mathrm{CO}_{3}\right)\left(\mathrm{SO}_{4}\right) \cdot 12 \mathrm{H}_{2} \mathrm{O} \rightarrow \mathrm{CaSiO}_{3} \cdot \mathrm{CaCO}_{3} \cdot \mathrm{CaSO}_{4} \cdot 2 \mathrm{H}_{2} \mathrm{O}+13 \mathrm{H}_{2} \mathrm{O}(7) \\
2 \mathrm{Ca}_{3} \mathrm{Si}(\mathrm{OH})_{6}\left(\mathrm{CO}_{3}\right)\left(\mathrm{SO}_{4}\right) \cdot 12 \mathrm{H}_{2} \mathrm{O} \rightarrow \mathrm{Ca}\left(\mathrm{HCO}_{3}\right)_{2}+\mathrm{Ca}\left(\mathrm{HSO}_{4}\right)_{2}+\mathrm{Ca} \\
(\mathrm{OH})_{2}+2 \mathrm{SiO}_{2}+3 \mathrm{CaO}+27 \mathrm{H}_{2} \mathrm{O}(7 \mathrm{a})
\end{gathered}
$$

2nd stage - 580-830 K, Dehydroxylation, Decarbonation and Desulphuration of $\mathrm{Ca}(\mathrm{OH})_{2}, \mathrm{Ca}\left(\mathrm{HCO}_{3}\right)_{2}$ and $\mathrm{Ca}\left(\mathrm{HSO}_{4}\right)_{2}[23,24]$

$\mathrm{CaSiO}_{3} \cdot \mathrm{CaCO}_{3} \cdot \mathrm{CaSO}_{4} \cdot 2 \mathrm{H}_{2} \mathrm{O} \rightarrow \mathrm{CaSiO}_{3} \cdot \mathrm{CaCO}_{3} \cdot \mathrm{CaSO}_{4}+2 \mathrm{H}_{2} \mathrm{O}$

or

$$
\begin{aligned}
& \mathrm{CaSiO}_{3} \cdot \mathrm{CaCO}_{3} \cdot \mathrm{CaSO}_{4} \cdot 2 \mathrm{H}_{2} \mathrm{O} \rightarrow \mathrm{CaSiO}_{3}+\mathrm{CaCO}_{3}+\mathrm{CaSO}_{4}+2 \mathrm{H}_{2} \mathrm{O} \\
& \mathrm{Ca}(\mathrm{OH})_{2} \rightarrow \mathrm{CaO}+\mathrm{H}_{2} \mathrm{O} \\
& \mathrm{Ca}\left(\mathrm{HCO}_{3}\right)_{2} \rightarrow \mathrm{CaCO}_{3}+\mathrm{CO}_{2}+\mathrm{H}_{2} \mathrm{O} \\
& \mathrm{Ca}\left(\mathrm{HSO}_{4}\right)_{2} \rightarrow \mathrm{CaSO}_{4}+\mathrm{SO}_{2}+\mathrm{H}_{2} \mathrm{O}+1 / 2 \mathrm{O}_{2}
\end{aligned}
$$$$
\text { 3rd stage - 900-1030 K, Decarbonation of calcite }
$$$$
\mathrm{CaCO}_{3} \rightarrow \mathrm{CaO}+\mathrm{CO}_{2}
$$$$
\mathrm{CaO}+\mathrm{CaSiO}_{3} \rightarrow \mathrm{Ca}_{2} \mathrm{SiO}_{4}
$$$$
\mathrm{CaCO}_{3}+2 \mathrm{Ca}_{2} \mathrm{SiO}_{4} \rightarrow \mathrm{Ca}_{5}\left(\mathrm{SiO}_{4}\right)_{2}\left(\mathrm{CO}_{3}\right)
$$$$
\mathrm{CaSO}_{4}+2 \mathrm{Ca}_{2} \mathrm{SiO}_{4} \rightarrow \mathrm{Ca}_{5}\left(\mathrm{SiO}_{4}\right)_{2}\left(\mathrm{SO}_{4}\right)
$$$$
\text { 4th stage - 1180-1320 K, Decarbonation of spurrite }
$$

$\mathrm{Ca}_{5}\left(\mathrm{SiO}_{4}\right)_{2}\left(\mathrm{CO}_{3}\right) \rightarrow 2 \mathrm{Ca}_{2} \mathrm{SiO}_{4}+\mathrm{CaO}+\mathrm{CO}_{2}$ 
5th stage - 1400-1670 K, Desulphuration of anhydrite and ternesite

$2 \mathrm{Ca}_{5}\left(\mathrm{SiO}_{4}\right)_{2}\left(\mathrm{SO}_{4}\right) \rightarrow 4 \mathrm{Ca}_{2} \mathrm{SiO}_{4}+2 \mathrm{CaO}+2 \mathrm{SO}_{2}+\mathrm{O}_{2}$

$2 \mathrm{Ca}_{5}\left(\mathrm{SiO}_{4}\right)_{2}\left(\mathrm{SO}_{4}\right) \rightarrow 4 \mathrm{CaSiO}_{3}+6 \mathrm{CaO}+2 \mathrm{SO}_{2}+\mathrm{O}_{2}$

$2 \mathrm{CaSO}_{4} \rightarrow 2 \mathrm{CaO}+2 \mathrm{SO}_{2}+\mathrm{O}_{2}$

\section{Conclusion}

The combination of instrumental techniques for high-temperature investigations - simultaneous TG/DTG-DSC (in different gas mediums) coupled with gas analysis, and in-situ PXRD, given the opportunity to clarify the solid-phase reactions and exact phase composition in the individual stages of thaumasite thermal decomposition.

The obtained new data allow comparing the reaction mechanisms of thaumasite thermal dissolution in oxygen and inert mediums. It has been proven, that thaumasite thermal decomposition proceeds with a higher degree of transformation into final products in the inert gas medium. This process takes place into one main stage of dehydration with 38.26 $\%$ ML in air and 39.21 \% ML in Ar medium and additional stages of: decarbonation with $6.92 \%$ ML in air and $7.48 \% \mathrm{ML}$ in Ar; and desulphuration with $9.71 \%$ ML in air and $10.23 \%$ in Ar medium. The transitional solid phases, grown with temperature increasing at different stages of thaumasite thermal decomposition are $\mathrm{Ca}\left(\mathrm{HCO}_{3}\right)_{2}, \mathrm{Ca}\left(\mathrm{HSO}_{4}\right)_{2}$, calcite, anhydrite, spurrite and ternesite. The end solid phases, grown at the highest temperatures, are larnite and $\mathrm{CaO}$.

The defined scheme of thaumasite thermal decomposition has both fundamental importance - adding new details of reference data, and also practical application for thaumasite identification - in chemical archaeology (complete scheme of thaumasite thermal decomposition), as well as in chemistry of cement and cement-based materials (the 1st and 2 nd stages of thaumasite thermal decomposition).

\section{Funding}

This work was supported by the Operational Program "Science and Education for Intelligent Growth" by the Bulgarian Ministry of Education and Science, co-financed by the European Union through the European Structural and Investment Funds under grant BG05M2OP001-1.0010008 of National Centre for Mechatronics and Clean Technology (V.P. and V.K-K.), and by the National Science Fund of Bulgaria under grant KP-06-N39/9 (B.K.).

\section{Projects contributions}

The grant BG05M2OP001-1.001-0008 of National Centre for Mechatronics and Clean Technology sponsors the following activities: experiments and measurements of XRD, in-situ XRD and TG/DTG-MS. The grant KP-06-N39/9 - experiments and measurements of TG-DTG/ DSC, FTIR, results interpretation. The contribution of both projects is $50 \%: 50 \%$.

\section{CRediT authorship contribution statement}

B. Kostova: Conceptualization, Writing - original draft, Visualization, Supervision, Project administration. V. Petkova: Conceptualization, Methodology, Investigation, Writing - original draft, Writing review \& editing, Visualization, Supervision, Project administration. Vl. Kostov-Kytin: Conceptualization, Visualization. Y. Tzvetanova: Investigation. G. Avdeev: Investigation.

\section{Declaration of Competing Interest}

The authors declare no conflict of interest.

\section{Acknowledgements}

The authors acknowledge the Department of Natural Sciences, Laboratory of Geology - BF at NBU (B.K.) and Institute of Mineralogy and Crystallography "Acad. I. Kostov", Bulgarian Academy of Sciences (V.P. and V.K-K. of K2-2020/2021).

The authors grateful acknowledge Nikolay Gospodinov for the provided raw sample from the Iglika deposit.

\section{References}

[1] H.F.W. Taylor, Delayed Ettringite Formation, 6th Conference, Advances in Cement and Concrete, 1994. Durham; NH, 122-131. ISBN:0784400342.

[2] J. Aguilera, J.S. Martınez-Ramırez, I. Pajares-Colomo, M.T. Blanco-Varela, Formation of thaumasite in carbonated mortars, Cement Concrete Comp. 25 (2003) 991-996, https://doi.org/10.1016/S0958-9465(03)00121-5.

[3] H.F.W. Taylor, Cement Chemistry, 2nd edition, Thomas Telford Publishing, London, 1997, https://doi.org/10.1680/cc.25929.

[4] G. Rajasekaran, Sulphate attack and ettringite formation in the lime and cement stabilized marine clays, Ocean. Eng. 32 (2005) 1133-1159, https://doi.org/ 10.1016/j.oceaneng.2004.08.012.

[5] N. Voglis, G. Kakali, E. Chaniotakis, S. Tsivilis, Portland-limestone cements. Their properties and hydration compared to those of other composite cements, Cement Concrete Comp. 27 (2005) 191-196, https://doi.org/10.1016/j. cemconcomp.2004.02.006.

[6] M.T. Blanco-Varela, J. Aguilera, S. Martınez-Ramırez, Effect of cement C3A content, temperature and storage medium on thaumasite formation in carbonated mortars, Cement Concrete Res. 36 (2006) 707-715, https://doi.org/10.1016/j. cemconres.2005.11.010.

[7] N. Crammond, The occurrence of thaumasite in modern construction - a review, Cement and Concrete Comp. 24 (3-4) (2002) 393-402, https://doi.org/10.1016/ S0958-9465(01)00092-0.

[8] M. Collepardi, Thaumasite formation and deterioration in historic buildings, Cement Concrete Comp. 21 (2) (1999) 147-154, https://doi.org/10.1016/S09589465(98)00044-4.

[9] S. Köhler, D. Heinz, L. Urbonas, Effect of ettringite on thaumasite formation, Cement Concrete Res. 36 (4) (2006) 697-706, https://doi.org/10.1016/j. cemconres.2005.11.006.

[10] S.M. Torres, C.A. Kirk, C.J. Lynsdale, R.N. Swamy, J.H. Sharp, Thaumasite-ettringite solid solutions in degraded mortars, Cement Concrete Res. 34 (8) (2004) 1297-1305, https://doi.org/10.1016/j.cemconres.2003.09.016.

[11] R. El-Hachem, E. Rozière, F. Grondin, A. Loukili, New procedure to investigate external sulphate attack on cementitious materials, Cement Concrete Comp. 34 (3) (2012) 357-364, https://doi.org/10.1016/j.cemconcomp.2011.11.010.

[12] J. Bensted, Thaumasite - background and nature in deterioration of cements, mortars and concretes, Cement Concrete Comp. 21 (1999) 117-121, https://doi. org/10.1016/S0958-9465(97)00076-0.

[13] C. Sabbioni, A. Bonazza, G. Zappia, Damage on hydraulic mortars: the Venice Arsenal, J. Cult. Herit. 3 (1) (2002) 83-88, https://doi.org/10.1016/S1296-2074 (02)01163-9.

[14] C. Sabbioni, G. Zappia, C. Riontino, M.T. Blanco-Varela, J. Aguilera, F. Puertas, K. Van Balen, E.E. Toumbakari, Atmospheric deterioration of ancient and modern hydraulic mortars, Atmos. Environ. 35 (2001) 539-548, https://doi.org/10.1016/ S1352-2310(00)00310-1.

[15] E. Ciliberto, S. Ioppolo, F. Manuella, Ettringite and thaumasite: A chemical route for their removal from cementious artefacts, J. Cult. Herit. 9 (1) (2008) 30-37, https://doi.org/10.1016/j.culher.2007.05.004.

[16] J.A. Durán-Suárez, M.P. Sáez-Pérez, R. Peralbo-Cano, V.M. Fernández-Martínez, Classical construction techniques in 17th century Jesuit architecture. Tools for the restoration of historic heritage, J. Cult Herit. 35 (2019) 154-160, https://doi.org/ 10.1016/j.culher.2018.04.024.

[17] A. Fabrizio, A. De Bonis, D. Miriello, S. Raneri, A. Silvestri, Geosciences for cultural heritage: an overview, J. Cult. Herit. 43 (2020) 338-341, https://doi.org/10.1016/ j.culher.2020.01.001.

[18] M. Drabik, L. Galikova, Method of thermal analysis in the detection of thaumasite and its presence in the sulphate-attacked concrete, Solid State Phenom. 90-91 (2003) 33-38, https://doi.org/10.4028/www.scientific.net/SSP.90-91.33.

[19] G.N. Kirov, C.N. Poulieff, On the infra-red spectrum and thermal decomposition products of thaumasite, $\mathrm{Ca}_{3} \mathrm{H}_{2}\left(\mathrm{CO}_{3} / \mathrm{SO}_{4}\right) \mathrm{SiO}_{4} \times 13 \mathrm{H}_{2} \mathrm{O}$, Mineral. Mag. 36 (283) (1968) 1003-1011.

[20] V.A. Drebushchak, Y.V. Seryotkin, S.N. Kokh, E.V. Sokol, Natural specimen of triple solid solution ettringite-thaumasite-chromate-ettringite, J. Therm. Anal. Calorim. 114 (2) (2013) 777-783, https://doi.org/10.1007/s10973-013-2989-3.

[21] P. Kresten, G. Berggren, The thermal decomposition of thaumasite from Mothae kimberlite pipe, Lesotho, Southern Africa, J. Therm. Anal. 9 (1) (1976) 23-28, https://doi.org/10.1007/bf01909260.

[22] D.J. Frost, Y. Fei, Stability of phase D at high pressure and high temperature, J. Geophys. Res. 103 (1998) 7463-7474, https://doi.org/10.1029/98JB00077.

[23] M. Drábik, D. Tunega, S. Balkovic, V.Š. Fajnor, Computer simulations of hydrogen bonds for better understanding of the data of thermal analysis of thaumasite, J. Therm. Anal. Calorim. 85 (2) (2006) 469-475, https://doi.org/10.1007/s10973005-7236-0. 
[24] M. Drábik, Thaumasite: its relevance to sulphate corrosion in concrete, Nachrichten Aus Der Chemie 59 (5) (2011) VIII-XI, https://doi.org/10.1002/ nadc. 201180415.

[25] M. Drábik, E. Scholtzová, Thermoanalytical events and enthalpies of phases and systems of the chemistry and technology of concrete. Part I. calcium-silicatealuminate-sulfate hydrates, Ceramics - Silikáty. 58 (3) (2014) 184-187.

[26] M. Drábik, L. Gáliková, E. Scholtzová, E. Hadzimová, Thermoanalytical events and enthalpies of phases and systems of the chemistry and technology of concrete. Part II. Hydrated cements, Ceram. Silikáty. 58 (4) (2014) 243-248.

[27] A. Martucci, G. Cruciani, In situ time resolved synchrotron powder diffraction study of thaumasite, Phys. Chem. Miner. 33 (10) (2006) 723-731, https://doi.org/ 10.1007/s00269-006-0124-8.

[28] P. Pipilikaki, D. Papageorgiou, D.C. Teas, E. Chaniotakis, M. Katsioti, The effect of temperature on thaumasite formation, Cement Concrete Comp. 30 (10) (2008) 964-969, https://doi.org/10.1016/j.cemconcomp.2008.09.004.

[29] P.M. Carmona-Quiroga, M.T. Blanco-Varela, Ettringite decomposition in the presence of barium carbonate, Cement Concrete Res. 52 (2013) 140-148, https:// doi.org/10.1016/j.cemconres.2013.05.021.

[30] M.A. Tantawy, Effect of high temperatures on the microstructure of cement paste, J. Mater. Sci. Chem. Eng. 5 (11) (2017) 33-48, https://doi.org/10.4236/ msce.2017.511004.

[31] V. Ivanova-Panayotova, M. Kanazirski, Monticellite magnesian skarns from the magmatic stage in the Iglika skarn deposit, Southeast Bulgaria, Geochem, Mineral Petrol. 30 (1995) 79-90.

[32] I. Kostov, V. Breskovska, Y. Mincheva-Stefanova, G. Kirov, The Minerals of Bulgaria, BAS Press, Sofia, 1964.

[33] Inorganic Crystal Structure Database (ICSD), Gmelin-Institut Für Anorganische Chemie and Fachinformation-szentrum FIZ Karlsruhe, 2005. http://icsd.fiz-karlsr uhe.de.icsd.html.

[34] S.D. Jacobsen, J.R. Smyth, R.J. Swope, Thermal expansion of hydrated sixcoordinate silicon in thaumasite, $\mathrm{Ca}_{3} \mathrm{Si}(\mathrm{OH})_{6}\left(\mathrm{CO}_{3}\right)\left(\mathrm{SO}_{4}\right) \cdot 12 \mathrm{H}_{2} \mathrm{O}$, Phys. Chem. Miner. 30 (2003) 321-329, https://doi.org/10.1007/s00269-003-0328-0.

[35] K. Momma, F. Izumi, VESTA 3 for three-dimensional visualization of crystal, volumetric and morphology data, J. Appl. Crystallogr. 44 (6) (2011) 1272-1276, https://doi.org/10.1107/S0021889811038970.

[36] Powder Diffraction File (PDF), ICDD, Newtown Square, PA, 2001. https://www. icdd.com/.

[37] R.A. Edge, H.F.W. Taylor, Crystal structure of thaumasite, a mineral containing [Si $\left.(\mathrm{OH})_{6}\right]_{2}$-groups, Nature. 224 (1969) 363-364, https://doi.org/10.1038/224363a0.

[38] R.A. Edge, H.F.W. Taylor, Crystal structure of thaumasite, $\left[\mathrm{Ca}_{3} \mathrm{Si}(\mathrm{OH})_{6} \cdot 12 \mathrm{H}_{2} \mathrm{O}\right]$ $\left(\mathrm{SO}_{4}\right)\left(\mathrm{CO}_{3}\right)$, Acta Crystallogr (B). 27 (1971) 594-601, https://doi.org/10.1107/ S0567740871002619.

[39] N.V. Chukanov, Infrared Spectra of Mineral Species: Extended Library, Springer Geochemistry/Mineralogy, 2014. ISBN: 978-94-007-7127-7,978-94-007-7128-4.

[40] I. Pekov, N. Chukanov, S. Britvin, Y. Kabalov, J. Goettlicher, V. Yapaskurt, A. Zadov, S. Krivovichev, W. Schüller, B. Ternes, The sulfite anion in ettringitegroup minerals: a new mineral species hielscherite, $\mathrm{Ca} 3 \mathrm{Si}(\mathrm{OH})_{6}\left(\mathrm{SO}_{4}\right)\left(\mathrm{SO}_{3}\right) \bullet 11 \mathrm{H}_{2} \mathrm{O}$ and the thaumasite-hielscherite solid-solution series, Mineral. Mag. 76 (2012), https://doi.org/10.1180/minmag.2012.076.5.06.

[41] E. Scholtzová, L. Kucková, J. Kožíšek, H. Pálková, D. Tunega, Experimental and computational study of thaumasite structure, Cement Concrete Res. 59 (2014) 66-72, https://doi.org/10.1016/j.cemconres.2014.02.002.

[42] N.V. Chukanov, S.N. Britvin, K.V. Van, S. Mockel, A.E. Zadov, Kottenheimite, $\mathrm{Ca}_{3} \mathrm{~S}$ $(\mathrm{OH})_{6}\left(\mathrm{SO}_{4}\right)_{2} \cdot 12 \mathrm{H}_{2} \mathrm{O}$, a new member of the ettringite group from the Eifel area,
Germany, Can. Mineral. 50 (2012) 55-63, https://doi.org/10.3749/ canmin.50.1.55.

[43] N. Chukanov, A.D. Chervonnyi, Infrared Spectroscopy of Minerals and Related Compounds, Springer Mineralogy, 2016, https://doi.org/10.1007/978-3-31925349-7.

[44] R. Titorenkova, E. Dyulgerova, V. Petkova, R. Ilieva, Carbonation and dehydroxylation of apatite during high energy milling of biphasic Ca-phosphate ceramics, Ceram. Int. 45 (6) (2019) 7025-7033, https://doi.org/10.1016/j. ceramint.2018.12.204.

[45] K. Nakamoto, Infrared and Raman Spectra of Inorganic and Coordination Compounds, 6th ed., Wiley, Hoboken, 2009. ISBN: 978-0-471-74339-2.

[46] V. Petkova, B. Kostova, M. Shopska, G. Kadinov, M. Baláž, P. Baláž, Behavior of high-energy-milling-activated eggshells during thermal treatment, J. Therm. Anal. Calorim. 127 (1) (2017) 615-623, https://doi.org/10.1007/s10973-016-5710-5.

[47] V. Stoyanov, B. Kostova, V. Petkova, Y. Pelovski, Structure of white cement mortars with high content of marble powder, J. Therm. Anal. Calorim. 110 (1) (2012) 405-412, https://doi.org/10.1007/s10973-012-2433-0.

[48] V. Petkova, V. Stoyanov, Y. Pelovski, TG-DTG-DTA in studying white selfcompacting cement mortars, J. Therm. Anal. Calorim. 109 (2) (2012) 797-806, https://doi.org/10.1007/s10973-012-2447-7.

[49] S. Skalamprinosa, G. Jen, I. Galan, M. Whittaker, A. Elhoweris, F. Glasser, The synthesis and hydration of ternesite, $\mathrm{Ca}_{5}\left(\mathrm{SiO}_{4}\right)_{2} \mathrm{SO}_{4}$, Cement Concrete Res. 113 (2018) 27-40, https://doi.org/10.1016/j.cemconres.2018.06.012.

[50] H. Bolio-Arceo, F.P. Glasser, Formation of spurrite, $\mathrm{Ca}_{5}\left(\mathrm{SiO}_{4}\right)_{2} \mathrm{CO}_{3}$, Cement Concrete Res. 20 (2) (1990) 301-307, https://doi.org/10.1016/0008-8846(90) 90084-B.

[51] A. Yin-Qing Zhang, A.V. Radha, A. Navrotsky, Thermochemistry of two calcium silicate carbonate minerals: scawtite, $\mathrm{Ca}_{7}\left(\mathrm{Si}_{6} \mathrm{O}_{18}\right)\left(\mathrm{CO}_{3}\right) \cdot 2 \mathrm{H}_{2} \mathrm{O}$, and spurrite, $\mathrm{Ca}_{5}\left(\mathrm{SiO}_{4}\right)_{2}\left(\mathrm{CO}_{3}\right)$, Geochim Cosmochim Ac. 115 (2013) 92-99, https://doi.org/ 10.1016/j.gca.2013.03.031.

[52] G. Goswami, B.P. Padhy, J.D. Panda, Thermal analysis of spurrite from a rotary cement kiln, J. Therm. Anal. Calorim. 35 (1989) 1129-1136, https://doi.org/ $10.1007 / \mathrm{bf01913030}$

[53] O.F. Tuttle, R.I. Harker, Synthesis of spurrite and the reaction wollastonite+calcite $<->$ spurrite+carbon dioxide, Am. J. Sci. 255 (1957) 226-234, https://doi.org/ 10.2475/ajs.255.3.226.

[54] M. Kamruddin, P.K. Ajikumar, S. Dash, A.K. Tyagi, B. Raj, Thermogravimetryevolved gas analysis-mass spectrometry system for materials research, Bull. Mater. Sci. 26 (2003) 449-460, https://doi.org/10.1007/BF02711191.

[55] H.Y. Ghorab, F.S. Zahran, M. Kamal, A.S. Meawad, On the durability of Portland limestone cement: effect of $\mathrm{pH}$ on the thaumasite formation, Hbrc J. 14 (3) (2018) 340-344, https://doi.org/10.1016/j.hbrcj.2017.04.002.

[56] O.I. Smith, S. Tseregounis, S.N. Wang, High-temperature kinetics of the reactions of $\mathrm{SO}_{2}$ and $\mathrm{SO}_{3}$ with atomic oxygen, Int. J. Chem. Kinet. 14 (6) (1982) 679-697, https://doi.org/10.1002/kin.550140610.

[57] P.B. Lawrence, L.K. Elliott, R.J. Stanger, R. Spörl, K.V. Shah, J. Maier, T.F. Wall, High-temperature conversion of $\mathrm{SO}_{2}$ to $\mathrm{SO}_{3}$ : homogeneous experiments and catalytic effect of fly ash from air and oxy-fuel firing, Energ Fuel. 28 (11) (2014) 7243-7251, https://doi.org/10.1021/ef5020346.

[58] P.J. Dunn, P.R. Koppula, H.G. Stenger, I.E. Wachs, Oxidation of sulfur dioxide to sulfur trioxide over supported vanadia catalysts, Appl Catal B-Environ. 19 (1998) 103-117, https://doi.org/10.1016/S0926-3373(98)00060-5. 